\title{
A Comparison of Korean-American Laws related to Special Education for Finding the Direction of Inclusive Education
}

\author{
Keoung Yeol Kim ${ }^{1}$ \\ ${ }^{1}$ Associate professor, Department of social welfare, Young San University, South Korea, \\ 007powerk3@gmail.com
}

\begin{abstract}
This study is aimed to find tasks for inclusive education in Korea through analysis of laws and regulations related to special education published in Korea and the United States. The purposes of the study are as follows. First, to compare and analyze the laws and regulations related to special education in Korea and the United States. Second, to examine the tasks of integrated special education in Korea. By comparing and analyzing the literature of the two countries, the following research results were derived. For this purpose, the analysis was focused on foreign and domestic literature and related laws and policy reports. In addition, in the case of laws and policy reports, related laws such as the Special Education Act for the Disabled, the Vocational Education and Training Promotion Act were examined. The collected data can be divided into domestic data and foreign data.. In detail, it is divided into degree claim thesis, another research thesis, related laws and policy report, etc., which the researcher reads, organizes, and analyzes the contents, and compares them. First, the special education law system of the United States is very advanced compared to that of Korea. The name has been clarified very concretely and realistically. Second, Korean laws related to special education are very advanced enough to be recognized as highly advanced laws in Asia, but the Special Education Promotion Act has no purpose and definition for evaluation, and the evaluation system has not been systematically established. In addition, compared to other countries, the definition of "learning disability" or "emotional disability" in Korea's Special Education Promotion Act is very abstract and very vague.
\end{abstract}

Keywords: Special Education Law, Inclusion Education, Social Welfare for the Disable, Policy for Special Education

\section{Introduction}

\subsection{Necessity of Research}

Since everyone is precious and noble, people should be respected and their rights should be protected no matter where they are. In a society, the rights of persons with disabilities are not guaranteed." This is because rights should be guaranteed not for the strong, but the weak. Based on this ideology, Korea enacted and promulgated the Charter on the Rights of Persons with Disabilities on December 9, 1998[1]. "Integrated education" to ensure the principle of normalization and equal educational opportunities is a concept suggested by the recent big trend of special education. In addition, the Ministry of Education of Korea proposed a plan to establish an education and welfare information network for the disabled in 1997 to establish a lifelong welfare support management system for the disabled, as well as various measures to ensure the right to education for the disabled. Announced. In addition, the proclamation of

*This study was revised and completed from the 2006 master's thesis.

Received: April 23, 2021; $1^{\text {st }}$ Review Result: June 7, 2021; $2^{\text {nd }}$ Review Result: July 24, 2021

Accepted: August 30, 2021 
the "UN Disabled 10 Years" and the "Asia Pacific Disabled 10 Years" is raising interest in welfare measures for the disabled in all countries[2]. In addition, the national strategy for the welfare state in the coming 21 st century is faced with the demand that investment and interest in education and welfare of the disabled can no longer be put off to the backside of other sectors. To meet the demands of the times, the government has recently prepared measures to develop special education, and is building and implementing an education and welfare information network for the disabled as one of the lifelong education and welfare systems for the disabled. In particular, social welfare policies and special education support policies have been reinforced, and the university's special education department has been expanded to cultivate special teachers. For these policies to be consistently enforced, the enactment and amendment of the law is necessary. For our society to become more mature and to develop into a higher level of civilization, efforts to enact or amend laws for inclusive education are needed with the interest and support of the people. Currently, Korea also improves the quality of life for persons with disabilities, such as the Special Education Act for the Disabled, the Act on Convenience Guarantee for the Disabled, Elderly, Pregnant Women, etc.

In 1982, the World Action Plan for the Disabled, which aimed for the 'full participation and equality of the disabled', was declared, and all countries set up and implemented an action plan suitable for their own setting. So, the Asia-Pacific Economic and Social Commission (ESCAP) prepared the 'Agenda for Action for the Asian and Pacific Decade of Disabled Persons: 1993 2002)', which revised the action plan for the disabled to fit the situation in the Asia-Pacific region in order to realize the 'full participation and equality of the disabled' ideology and have them establish and implement a plan. In 1993, the UN 48th General Assembly adopted the "Standard Principle for the Realization of Equal Opportunity for Disabled Persons" to emphasize the commitment to integrated education. In 1994, the Minister of Education of the Federal Republic of Germany, "Parents wish for integrated education, and if schools accept it, they should recognize integrated education.",In particular, the integrated facilities at the OECD meeting in 1995 emphasized the integration of students with disabilities and non-disabled students, considering that they are much more economical until they become social life in the future than investing in separate facilities.,In addition, OECD has implemented integration into various types (i.e., integratedspecial school facilities, integrated full-time mainstream class, integrated arrangement, integrated 2social integration-non-regular curriculum, and 3 functional integration-same class according to the same curriculum).,And UNESCO is demanding government-level efforts to improve the system, provide high political and budget support, and allow general school math for children with severe disabilities for the education of all children.

Many laws have been enacted and amended. In particular, in 1994, with the full amendment of the Special Education Promotion Act, Korea laid the foundation for inclusive education, ensuring the right to education in the same educational environment as students with disabilities and general students. The Special Education Act for the Disabled, etc. provides an environment for inclusive education to persons with disabilities and those with special educational needs, and provides education in consideration of the life cycle, type of disability, and degree of disability, so that they can realize their self and contribute to the integration of society. It was enacted on May 25, 2007 for this law.

\subsection{Research Problems}

In the philosophy of respect for humanity, it is natural that all children should be provided with equally meaningful educational opportunities, and that educational opportunities appropriate to their abilities should be provided. Therefore, students with disabilities have the right to live in a normal environment from birth to death. From an educational standpoint, it can be said that they have the right to receive education in the same learning environment as ordinary students. In other words, you must receive inclusive education in a minimally restricted environment. Therefore, this study has two purposes. First, 
it compares and analyzes the laws and regulations related to special education in Korea and the United States. Second, it examines the tasks of integrated special education in Korea. The principle of respect for human beings is inherent in the need to provide meaningful educational opportunities to all children equally and to provide educational opportunities suitable for their abilities. Therefore, students with disabilities have the right to live in a normal environment from birth to death. From an educational point of view, it can be said that students have the right to be educated in the same learning environment as general students. In other words, they should receive inclusive education in a minimally limited environment. In order to prepare an alternative to inclusive education in Korea, the purpose of this study is to compare the special education policies of the United States and Korea, which are doing well in inclusive education. This study has two purposes. First, we compare and analyze the laws and regulations related to special education in Korea and the United States. Second, the task of integrated special education in Korea is to be investigated.

\section{Research Methodology}

This study focuses on the two countries (USA and South Korea) that have chosen the legal system for the realization of inclusive education, and examines established is the inclusive education environment as a result of the legal system reorganization. The following items were comparatively analyzed between Korea and the United States. For this purpose, the analysis was focused on foreign and domestic literature and related laws and policy reports. "In addition, in the case of laws and policy reports, related laws such as the Special Education Act for the Disabled, the Vocational Education and Training Promotion Act, etc., national and provincial offices of education level curriculum organization and operation guidelines, statistical data, and prior research are the subjects of investigation. This study compared and analyzed the research achievements of special education scholars from two selected countries, as well as literature data obtained through direct visits to related sites. Materials provided by the Ministry of Education, Science and Technology, National Central Library, Daegu University Library, and the National Institute of Special Education were mainly collected. In addition, data obtained from the Office of the Human Rights Association for the Education of the Disabled were also referred to. The collected data can be divided into domestic data and foreign data. In detail, it is divided into degree claim thesis, another research thesis, related laws and policy report, etc., which the researcher reads, organizes, and analyzes the contents, and compares them. From 2001 to 2020, studies on policy of special education in USA and South Korea were analyzed. First, data were obtained by computer search for papers from 2001 to 2020 with search terms such as special ducation, special education law and policy. Second, the research results were derived by examining the theoretical concepts of the selected papers through content analysis.

\section{Contents}

From the early 1970s, laws for the education and welfare of the disabled were gradually enacted to accommodate large and small movements for inclusive education (requests from various parent groups with disabilities and special education-related organizations) and social changes. In particular, in Korea, the policy direction for providing services from segregated education to inclusive education was prepared only when the Special Education Promotion Act was revised in 1994, and more active policy support from the existing full-time special classes and part-time integration to full integration was implemented. prospect. This study examines the enactment and revision of special education-related laws that can help inclusive education in both countries. 


\subsection{America}

Special education in the United States began in the early 19th century. It was a time of belief and optimism about human potential. Special education in the United States has been started and developed mainly by people who have gone to European countries such as France and the UK to learn special education, and people who have immigrated from Europe. This country's special education, which started with education for deaf children and blind children by individuals or private organizations, did not provide educational opportunities to all children with disabilities. Therefore, groups such as the Committee for Special Children and the Parents' Association for Disabled Children, which were formed in 1922, started to engage in activities for the disabled as advocates for the disabled. As a result, there have been many precedents that make governments legally obligated to educate children with disabilities. Due to the activities and precedents of these advocacy groups, the Ministry of Health, Education, and Welfare established a special education department in 1966 and provided financial support for special education programs. However, many children with disabilities were unable to continue their education and were misclassified and placed. So the 'silent revolution' began.

During this revolution, which began in 1970, the procedures for identification, classification, and assessment of children with disabilities were criticized, and they were subject to lawsuits and legal action. And in the lawsuit, it was decided that children with disabilities were misclassified and placed. The 'Quiet Revolution' reached its demise in April 1975. At that time, more than 1.75 million children with disabilities were excluded from education because of their disabilities, and more than $50 \%$ of children with disabilities did not receive adequate education or were placed in poor educational environments. More than 50\% of states have filed lawsuits with these issues. Before 1975, when the Education for All Handicapped Children Act, PL 94-142, was enacted, there was no satisfactory special education in the United States. At that time, the US Congress enacted the (former) Children with Disabilities Education Act (Public Law 94-142) in 1975 (actually amended), which is the historical law of the current Disabled Education Act. There was a recognition that it was in the best interests of the country to intervene and work jointly with the state[1].

\subsubsection{Elementary Education and Secondary Education Act of 1965}

This Act (PL89-10) went into effect in 1965 and, beginning in 1969, required special measures from the federal government for children from low-income families and for children who are more likely to be academically retarded. Moreover, it has become a law that places learning disabilities as a part of special education and makes education measures compulsory. The Elementary and Secondary Education Act was amended in 1969 and part of it became the 'Education Act for Children with Learning Disabilities'. This legislation is known as the Yar-borough Act, named after the Yar-borough elected member of the state of Texas[2].

\subsubsection{Education for All Handicapped Children Act: EHA,1975}

The federal financial aid program to expand educational opportunities for children with disabilities was originally established in the Elementary and Secondary Education Act of 1965, but the Education of the Handicapped Act (EHA) of 1970 As it was enacted, its contents were transferred to this Act. With the enactment of the American Children with Disabilities Education Act of 1975, special education in the United States brought about a drastic change. The United States Children with Disabilities Education Act stipulates that local school districts must develop an Individualized Education Program (IEP) for each student with special education needs, and specifies the special education services to be included in the individualized education plan. The Act emphasized six principles of 1) adequate free public education, 2) non-discriminatory evaluation, 3) individualized curriculum (IEP), 4) minimally restricted 
environment, 5) due process, and 6) parental participation[2].

\subsubsection{Individuals with Disabilities Education Act, 1990}

PL 99-457 was newly revised in 1990 under the name IDEA (PL 101-476). The name change was the result of changing the name to "Individuals with Disabilities" in line with the "People First Language" movement, which has been used to describe people with disabilities, such as "Handicapped People". 1990 The revision of IDEA is the first change in the concept of acknowledging people first, the fact that autism and brain damage was added to the subjects of special education, and the fact that a transition education plan should be established from the age of 16. The Education Act provides for appropriate Free and Appropriate Public Education (FAPE), least restrictive educational environments, i.e., Least Restrictive Environment (LRE), Individualized Education Programs (IEPs), and safeguards associated with them. This law is essentially a human rights law for persons with disabilities, which stipulates that schools, workplaces, and government departments provide convenience for persons with disabilities to participate in daily life to the maximum extent possible (Hallahan \&amp; Kuffman, 2000). This public law upholds civil rights and stipulates not to discriminate in the employment of persons with disabilities. According to this law, companies with 15 or more employees from 1994 onwards, if they have an aptitude for occupations with disabilities, their gender and disability In this case, employers are obliged to take necessary measures to enable persons with disabilities to perform their duties.

\subsubsection{Individuals with Disabilities Education Act: IDEA, 1997}

To further enhance the effect of special education, the Americans with Disabilities Education Act, which was revised and reapproved again in June 1997, consists of Part 4, Part A is the general provisions of Article 601 ( It consists of 7 articles from Section 601) to Article 607, and Part B (Part B) consists of 9 articles from Articles 611 to 619 as regulations for the education of the disabled from 3 to 21 years old. . Part C (Part C) is the regulations for educating infants and young children with disabilities, and consists of 15 articles from Articles 631 to 645. Part D (Part D) includes research on education for the disabled, dissemination of information, etc. It stipulates federal government-implemented projects for the education of persons with disabilities, and consists of Articles 651-656, 661, 671-674, and 681-687. In 1997, as amended by the Education for Persons with Disabilities (IEDA), it was re-approved (PL 105-17), and the writing period for the transition education plan was reduced to 14 . In addition, this law gave all children with disabilities aged 3 to 21 the right to receive free education, and stipulated that special education should be conducted in the least restrictive environment. Education in the least restrictive environment means that children with disabilities should be educated in the same place as children without disabilities, and only those children who cannot achieve satisfactory results in a general class even with the use of assistive devices and supplementary support are special. This means that they should be educated in a classroom or special school. This law stipulates that an individualized education plan suitable for all children with disabilities is established and documented. allowed to participate in the creation of Parents must approve the contents of special education, and if parents do not agree with the contents of the individualized curriculum, the right to sue the school was recognized, so a large amount of money had to be spent on litigation costs. And since schools have to pay for sending students to expensive private schools that parents want, the cost of implementing IDEA has become increasingly burdensome. Therefore, the 1997 amendment strengthened that parents must have a meeting with the school authorities for mediation before hiring a lawyer to file a lawsuit, and that admission to a private school must be paid after the decision is made through such mediation. It also gave the parent access to all documents about the child with a disability, gave them the right to appeal if they could not agree to the placement of their child, and made the federal government obligated to pay for special education. In addition, the law has protected students with disabilities from suspension, but it has been argued that 
this is a double norm as ordinary students can be suspended as a way of regulating their behavior. The law amended in 1997 stipulated that students with disabilities could also be suspended. However, there is a proviso that education must be continued by replacing it with other educational opportunities.

\subsubsection{No Child Left Behind Act(2001)}

Congress passed the No Child Left Behind Act (NCBL) in 2001. This law reformed the Elementary and Secondary Education Act of 1965. The Act emphasized accountability to all students, including students with disabilities, and emphasized 1) strong accountability for outcomes 2) expanded the flexibility of local controls 3) expanded parental options 4) taught in a proven way (National Center on Educational Outcomes, National Center on Educational Outcomes, 2003). During the 2013-2014 school year, the state engages all students, including students with disabilities, in state-level assessments and improves academic performance to a satisfactory level, and each school provides all students with math, reading and language skills from the first year to the following year. Skills were measured as targets for appropriate training progress[3].

\subsubsection{Individuals with Disabilities Education Act:IDEA, 2004}

The Americans with Disabilities Education Act, recertified in 2004, requires that special education teachers meet the requirements required to become fully qualified and qualified teachers as outlined in United States statutes to obtain special education certification. In other words, teachers with sufficient qualifications and qualifications specified in the US Education Act (No Child Left Behind) must satisfy the following three conditions: a bachelor's degree, a state teacher's certificate, and related knowledge of the subjects they teach.

\subsection{South Korea}

\subsubsection{Constitution}

The Constitution of the Republic of Korea stipulates that 'every citizen has dignity and value as a human being, has the right to pursue happiness, and the state must confirm and guarantee the inviolable basic human rights of individuals' (Article 10). Therefore, as a member of the socity, disabled people have the same rights as other citizens, and the state must guarantee the human rights of people with disabilities. And Article 11(1) of the Constitution states, 'All citizens are equal before the law. No one shall be discriminated against in all areas of political, economic, social and cultural life based on gender, religion or social status', supporting the basic right of persons with disabilities not to be discriminated against in any field. In addition, the Constitution stipulates that all citizens have the right to receive education equally according to their abilities (Article 31 (1)), the right to work (Article 32 (1)), and the right to lead a dignified life (Article 34 (1)). Persons with disabilities who have unique characteristics different from ordinary people due to physical and mental disabilities have basic rights such as the right to education to receive appropriate education according to their abilities, the right to work, and the right to live like a human being. is declaring In particular, Article 34 (5) of the Constitution stipulates that 'People with disabilities and citizens who are incapable of living due to disease, old age or other reasons shall be protected by the state as prescribed by law'. makes it clear that they have the right to the protection of As such, the Korean constitution provides that disabled people have basic human rights as citizens, are given an education appropriate to their abilities, are guaranteed the right to work, and in any case, can receive protection from the state. It shows the characteristics of pursuing realization[4].

\subsubsection{Elementary and Secondary Education Act}

The Elementary and Secondary Education Act (Law No. 5438) for early childhood education and elementary and secondary education by the provisions of the Basic Education Act stipulates matters 
related to compulsory education, students and staff, and schools. According to this Act, the types of schools are divided into kindergartens, elementary and civic schools, middle schools and high schools, high schools and technical schools, special schools, and various schools (Article 2). It is stipulated that the establishment and management of elementary and junior high schools and special schools that educate elementary and middle school courses necessary to enroll all persons eligible for education (Article 12 (2)), prevent the establishment and management of special schools for elementary and middle school courses. It is the duty of the heads of local governments. According to Articles 55 and 56 of this Act, special schools provide education equivalent to kindergarten, elementary school, middle school, or high school for those in need of special education due to physical, mental, or intellectual disability, as well as education on knowledge, skills and social adaptation necessary for real life. In order to provide specialized technical education to graduates of the relevant course (including graduates of special classes in high school) in a special school that has established a high school course, a major with a teaching period of at least one year may be established., Article 57 stipulates that special classes for students in need of special education may be established in schools at each level of high school or lower with the approval of the competent authority. In addition, a person who has completed a curriculum equivalent to an elementary school, middle school, or high school in a special school or special class is deemed to have the same educational background as a person who has graduated from the corresponding school (Article 58). It is recognized as equivalent to a general school. In this way, the Elementary and Secondary Education Act, which stipulates the types of schools necessary for early childhood education and elementary and secondary education, as well as matters related to students and staff, recognizes special schools as an official type of school, and the academic background of special schools and special classes is generally accepted. It is recognized on an equal basis with the school, and necessary details are stipulated[4].

\subsubsection{Act on Special Education for Persons with Disabilities, etc.}

The Korea Special Education Association, which was formed to promote the development of special education, insisted on the enactment of the Special Education Act through various training seminars and lectures since March 1962, and submitted a complaint to the Supreme Council for National Reconstruction. The necessity was appealed to the related urologists, but at that time, compulsory education in elementary schools was not implemented properly. In the 1970s, it began to be reflected in education policy, and then, along with the development of the country, the social awareness of the disabled and the need for special education increased in the sense that education welfare that guarantees equal educational opportunities for all people was achieved. The Education Promotion Act was enacted (December 31, 1977). The biggest achievement of the Special Education Promotion Act was that students in private special schools as well as national and public schools were able to benefit from free education up to compulsory education courses. In this way, although children with disabilities greatly contributed to the provision of educational opportunities and the quality improvement of special education, as time went by, the demand for special education was expected, the rapid construction and expansion of special education institutions, and parents' rights claims, etc. Circumstances have changed significantly, and the demand for amendments of the Act has increased to accommodate them. In response to these demands, in 1977, in order to solve the problem of not properly reflecting the rapid changes in educational conditions as all sectors of politics, economy, and society in Korea change and develop, and to meet the demand for special education that has been rapidly increasing recently, 1977 The Special Education Promotion Act, enacted in, went through several revisions until 2005. The 'Special Education Act for Persons with Disabilities, etc.', which was enacted on May 25, 2007 and enforced on May 26, 2008, is a law based on Article 18 of the Framework Act on Education. The purpose of this law is to provide an environment for inclusive education to persons with disabilities and special 
educational needs, and to provide education in consideration of the life cycle, type of disability, and degree of disability, so that they can realize their self and contribute to the integration of society.

\section{Conclusions}

There are laws for a better life for the disabled and laws to promote special education, so there are differences in the implementation details, but both countries support special education at the national level. Unlike Korea, it can be seen that the laws of states and special districts in the United States enact and enforce their laws similar to federal laws in each state. The characteristics of the special educationrelated laws of the two countries can be summarized as follows in [Table 1].

[Table 1] The comparison of content on policy of special education in USA and South Korea

\begin{tabular}{|c|c|c|}
\hline & USA & South Korea \\
\hline $\begin{array}{c}\text { The right to learning of students with } \\
\text { disabilities }\end{array}$ & Specified in detail & Less specified in detail \\
\hline The responsibility of government & Provided financial support & Provided less financial support \\
\hline $\begin{array}{c}\text { The content of stipulation related } \\
\text { vocational education }\end{array}$ & Provided at an early stage & Less provided at an early stage \\
\hline
\end{tabular}

First, we can see the traces of US special education-related laws that have been continuously coming towards inclusive education from a very long time ago. The right to learning of students with disabilities is specified in detail. Compared to the laws related to special education in the United States, the laws related to special education in Korea do not have (1) the purpose and definition of evaluation, and the evaluation system is not systematically established. However, although there is information on diagnosis and evaluation in the regulations on the selection and placement of special education recipients, it is not evaluated in the field of special education, but is replaced by a welfare card for the disabled or a doctor's diagnosis (Ansu Lim, 2005). Also, in Korea's special education-related laws, (2) the definition of 'learning disability' or 'emotional disability' is very abstract and very vague. (3) there is no regulation that makes the transition education plan mandatory for infants, toddlers and high school students (Education Act for Children with Disabilities, 1986). The age at which transition education begins for students with disabilities in the United States has been lowered from 14 to 16 (recertified in 2004). In addition, (4) in Korea, there are no measures for disabled students to receive education even if they are expelled from school. However, the 1997 IDEA in the United States states that all children with disabilities must continue to receive special education services, even if they are expelled from school.

Second, the current Act on Education for Persons with Disabilities in the United States is the 1997 Amended Act (Public Law 105-17). As such, the Americans with Disabilities Education Act improves educational conditions while the federal government provides financial support for state special education. Instead, the U.S. Department of Education (the Office of Special Education and Rehabilitation) checks how well states adhere to the Disability Education Act. In addition, with the enactment of the American Children with Disabilities Education Act in 1975, the environment for inclusive education changed rapidly. Although the environment of inclusive education varies from state to state, in general, the legal regulations are more realistic than in other countries (recognizing the right to sue the school if parents do not agree with the contents of the individualized curriculum, parents needing a lawyer) It has been reinforced that a meeting with the school authorities for mediation must be held before hiring and litigation, and that admission to a private school must be paid after the decision is made through such mediation, etc.)[5]. 
Third, unlike other countries, the US stipulates that vocational education can be provided at an early stage (revision of IDEA in 1990 made it mandatory to establish a transitional education plan from the age of 16). In addition, IDEA 97 and its statutes stipulate that each state government should prepare effective policies and procedures that can prove to a level that the Minister of Education can prove to a level that the Minister of Education can satisfy for inclusive education[6].

When analyzing and comparing the special education related laws and special education related systems in the United States, these countries are improving the special education related laws quickly to follow the trend in integrated education. However, each country has different economic and social backgrounds, so it has laws and systems in various forms.

First, special education has been developed into integrated education and separate education, and long ago, students with disabilities were educated separately, but the movement of integration began to take place with the introduction of the concept of normalization in 1960.,In other words, the reform of special education focusing on integrated education from the environment where the disabled students were educated mainly in separate education was defined to be able to educate with peer students in order to meet the unique needs of the disabled students in the LRE, the minimum limited environment, in 1975.,Continuing efforts led to the General Education Initiative (REI).,However, teachers have been criticized for REI while facing a dilemma that minimizes the difference between groups compared to maximizing average performance ability. After that, it has been developed into a so-called full inclusion that merges special education and general education into an integrated system to meet the educational needs of all students regardless of disability or ability.

Second, the United States enacts and enforces laws similar to its own federal laws in each state.,As a result of comparing and analyzing the characteristics of US special education laws, the US Special Education Law for the Disabled supports the federal government to provide special education to the state, and supports the state to improve educational conditions.,Instead, the U.S. Department of Education (Special Education and Rehabilitation) checks the state's compliance with the Disability Education Act., The special education law of the United States is very realistic (the contents of the individualization curriculum are recognized by parents if they do not agree with the contents of the individualization curriculum, the contents of which are reinforced to meet with the school authorities for arbitration before the parents hire a lawyer and file a lawsuit, and the admission of private schools is also charged after such arbitration).

In addition, the United States stated that vocational education can be done early (the IDEA revision in 1990 is the first change in the concept of recognizing people first, and the fact that autism and brain damage are added to special education subjects and the mandatory transition education plan should be established from the age of 16), Finally, IDEA 97 and its laws stipulate that each state government should prepare effective policies and procedures to prove to the level that the Minister of Education can satisfy for integrated education.

Third, Korea attempted to implement the integrated education for female students in Pyeongyang in the early 1900s by Mrs. Hall. However, in terms of related laws and systems, the regulations related to compulsory, free and integrated education of students with disabilities are less advanced compared to the United States and the United Kingdom, and the integrated education of students with disabilities has been tried in many ways in recent years. As we can see from the rapidly developed integrated education environment through the Special Education Promotion Act revised in 1994, proper regulations should be firstly improved for better integrated education. When the improvements are complemented compared to the special education laws of the United States, a better integrated education environment will be developed in Korea.

The implications and findings of this study through comparing and analyzing the laws and special education systems related to special education in the United States and Korea are as follows. First, it is necessary to consider the unique educational environment of Korea, but it will contribute greatly to the 
formation of future integrated education model if Korea studies the integrated education process of developed countries and influences the development of global integrated education. Second, in the special education promotion law of Korea, the enforcement ordinance or enforcement regulations are not very specific and abstract.,It is necessary to compare and analyze the legislative forms and application procedures of developed countries and to conduct research that can be applied in detail to the field of our education. Third, the diagnosis and evaluation section should be clear for the proper education of students with disabilities, but the Special Education Promotion Act is neglected.,In addition, in order to return to society smoothly, the contents of the laws and regulations are very poor compared to the laws of developed countries.,It is necessary to understand the problems of on-site special education diagnosis and evaluation, which are easy to proceed formally, and vocational education, and to collect opinions on improvements to make legislative policies to help smooth socialization of the disabled. Fourth, the United States is ahead of the economic level or welfare level of Korea, and it is necessary to study the comparison of special education laws and integrated education in Korea and in many countries.

This study has several limitations that arise from the problem of relying on a literature review. First, the limitation is that it relies mostly on literature research and does not deal with specific details because it is a study that compares the huge framework of education for the disabled. Second, the limitation is the selection of countries to be compared. Whether the United States, the country selected for this study, is suitable for the study. As is known, these countries are ahead of ours in education and welfare for the disabled. It is questionable to what extent desirable improvement measures can be derived by comparing other countries with ours without considering the social and cultural environment and level.

\section{References}

[1] W. K. Kim, Special Education Law Theology, Korea: Book Publishing Special Education, (2004)

[2] H. M. Park, New Trends in World Special Education, Korea Seoul: Haksisa, (1999)

[3] B. B. Strickland, A. P. Turnbull, Developing and implementing Individualized Education Programs(3rd ed), USA Columbus, OH: Merrill, (1990)

[4] A. Rebora, No Child Left Behind, Education Week, (2004), https://www.edweek.org/policy-politics/no-child-leftbehind/2004/09

[5] J. H. Kim, Perception of Educational Administrators on Integrated Education for Students with Disabilities, Kongju National University, Master's Thesis, (2002)

[6] Y. S. Lim, The Legal Comparison of integrated education between the United State and Korea, Asia-Pacific Journal of Intellectual Disabilities, (2003), Vol.4, No.4, pp.21-39. 